\title{
Development of sulfonate-functionalized hydroxyapatite nanoparticles for cadmium removal from aqueous solutions
}

\begin{abstract}
Sulfonate-functionalized hydroxyapatite was successfully synthesized by organofunctionalization using natural phosphate and Benzenedisulfonate molecules. The modified apatites were characterized using multiple techniques, evidencing the effective incorporation of organo-functional groups into the hydroxyapatite matrix. Sulfonated mesoporous hydroxyapatite possesses a large amount of accessible $-\mathrm{SO}_{3}$ acid groups, which may be versatile adsorbents for the binding of Cd(II) cations. Stability issues of the sulfonated HAp nanocomposites for the specific reactions are addressed. The sulfonated hydroxyapatite nanopowders were evaluated cadmium removal from water. Adsorption tests reveal the efficiency of the hybrid apatites for cadmium removal $\left(\mathrm{q}_{m}=457 \mathrm{mg} \mathrm{g}^{-1}\right)$. Experimental results fit the Ho-second-order kinetic model for chemical adsorption. Two possible adsorption controlled mechanisms of $\mathrm{Cd}(\mathrm{II})$ ions at the apatite surface, complexation and dissolution/precipitation, are proposed.
\end{abstract}

Keywords. Functionalization, Hydroxyapatite, Organosulfonate, Nanocomposites, Adsorption

\section{Introduction}

Water and soil remediation technologies have become a subject of primary concern in the scientific community [1]. Heavy metals, which tend to bioaccumulate must be removed from water [2-4]. Cadmium is a heavy metal of considerable environmental and occupational concern and is classified as carcinogen by several regulatory agencies and authors [3-4,]. Its disposal from water involves treatments such as sorption and ion exchange, precipitation and 
membrane processes. Among them, sorption is considered as the most promising due to its cost-efficiency [5]. It is also the most used method for its feasibility and effectiveness [6]. To further reduce the cost of the process, it is suitable to elaborate new hybrid nanopowders with improved surface properties. The development of hybrid materials has gained a phenomenal impulsion in wastewater remediation with zeolite-imidazolate frameworks [7], fulvic acidaided Hydroxyapatite [8], ethyl acrylate grafted chitosan [9], activated carbon [10], functionalized silica [11] and poly(aniline-co-m-phenylenediamine)/ $\mathrm{Fe}_{3} \mathrm{O}_{4}$ nanocomposites [12], Sulfonated magnetic nanocomposite based on reactive PGMA-MAn copolymer/ $\mathrm{Fe}_{3} \mathrm{O}_{4}$ [13], which revealed capable of heavy metal removal from aqueous solutions. Hydroxyapatite (HAp) is well known for its retention of heavy metals [14-15]. However, recent reports suggest that HAp material exhibits low specific surface area and pore size. Surface modification of HAp with organic functions is an efficient procedure to design materials with improved surface properties. Limited studies have shown that it is possible to exchange $\mathrm{PO}_{4}{ }^{3-}$ ions with organic groups as surface modifiers of HAp nanoparticles [16-20]. Based on the high reactivity and stability of HAp, the ability of sulfonate species to exchange with the phosphate of HAp crystals reveals a number of new active sites that are able to interact with toxic species present in water. Several sulfonated materials were used as adsorbents for metal remediation such as sulfonated mesoporous silica [21], sulfonated graphene oxide [22], sodium alginate [23], sulfonated cellulose [24], Sulfonated Graphene Nanosheets [25-26] double layered hydroxide [27] and functionalized chitosan [28]. As a result, organosulfonate should have a greater affinity for heavy metals upon improving the surface properties of the resulting hybrid materials. In this respect, Benzenedisulfonate (BDS) has two sulfonic groups $\left(\mathrm{SO}_{3}{ }^{-}\right)$and can form strong bonds with HAp to form a hybrid HAp that is able to interact with $\mathrm{Cd}(\mathrm{II})$. Up to our knowledge, there was no report on BDS grafting onto the HAp matrix exhibiting better surface properties. Current work develops a new apatite hybrid by BDS 
grafting using phosphate rock as $\mathrm{Ca}^{2+}$ and $\mathrm{PO}_{4}{ }^{3-}$ precursors. These hybrid-sulfonated materials with a uniform microstructure are tested for cadmium capture.

\section{Materials and methods}

\subsection{Preparation of $w B D S-H A p$ nanopowders}

The pure nanohydroxyapatite was synthesized from the natural phosphate (NP) that comes from Bengurir ore (Morocco) via a dissolution/precipitation method already described previously [29-30]. As reported elsewhere [31], natural phosphate consists of carbonated fluorapatite with a little amount of silica (2wt.\%) and organic matter (ca.1.5wt.\%). It possesses a low specific surface area $\left(20 \mathrm{~m}^{2} \mathrm{~g}^{-1}\right)$. Using the same method described in our published work [29], the sulfonated hydroxyapatite samples, named BDS-HAp, were prepared from the dissolution of natural phosphate and sodium benzene-1,3-disulphonate, molecules $\mathrm{C}_{6} \mathrm{H}_{4}\left(\mathrm{SO}_{3} \mathrm{Na}\right)_{2}$ (BDS) (Fig.S1). After dissolution of the natural phosphate and the recovery of the filtrate containing the calcium and phosphorus precursors, an aqueous solution of BDS is added. The mixture is then neutralized with concentrated ammonia $(25 \%)$ to $\mathrm{pH}=10$ with continuous stirring at room temperature. As it is realized in the preparation of HAp, the resulting pseudo-gels are dispersed several times in water under ultrasonication. The quantity of additional BDS was varied to obtain theoretical final BDS:HAp weight ratios $\mathrm{w}=5,10$, and $15 \%$ and the resulting materials were named wBDS-HAp. The precipitates were dried at $100^{\circ} \mathrm{C}$ and the resulting powders were calcined at $800^{\circ} \mathrm{C}$ to study their thermal stability.

\subsection{Techniques}

The powders were identified using a Philips PW131 diffractometer. Infrared spectra were recorded in the 400 to $4000 \mathrm{~cm}^{-1}$ range on a Bruker IFS66v Fourier Transform Spectrometer. The $\mathrm{N}_{2}$ adsorption-desorption isotherms for the dried powders were obtained by multipoint sorption experiments using a Belsorb instrument. Specific surfaces were calculated according to the BET method in the $0.05-0.25$ relative pressure range. Pore size distributions were 
determined using BJH approximation. Chemical analyzes were performed by ICP-AES and EDX analyses. The particle morphologies were determined by using SEM/EDX on a JEOL/EO IP100, and TEM on a Tecnai Spirit G2 operating at $100 \mathrm{kV}$.

\subsection{Sorption experiments}

The stock solution of $2 \mathrm{gL}^{-1} \mathrm{Cd}(\mathrm{II})$ was prepared by dissolving $\mathrm{Cd}\left(\mathrm{NO}_{3}\right)_{2}$ in distilled water. The test solutions were obtained by serial dilution of primitive $\mathrm{Cd}$ solution and adjusted to $\mathrm{pH}$ 5 by using either $\mathrm{HCl}$ or $\mathrm{NaOH}$. Kinetic studies were conducted by mixing $100 \mathrm{~mL}$ of $\mathrm{Cd}(\mathrm{II})$ solution of $100 \mathrm{mg} / \mathrm{L}$ with $200 \mathrm{mg}$ of sorbent. Aliquots of the supernatant solution were taken and filtrated with a $0.45 \mathrm{~mm}$ filter. Residual $\mathrm{Cd}^{2+}$ concentration was determined by flame atomic adsorption spectrophotometer. The amount of sorbed $\mathrm{Cd}(\mathrm{II})\left(\mathrm{q}_{\mathrm{t}}\right.$ in $\left.\mathrm{mg} \mathrm{g}^{-1}\right)$ at time $\mathrm{t}$ was calculated as follows: $\mathrm{q}_{\mathrm{t}}=\mathrm{V} .\left(\mathrm{C}_{0}-\mathrm{C}_{\mathrm{t}}\right) / \mathrm{m}$, where $\mathrm{C}_{0}$ and $\mathrm{C}_{\mathrm{t}}$ are the initial cadmium concentration (in $\mathrm{mg} \mathrm{L}^{-1}$ ) in the liquid phase and at any time $\mathrm{t}$, respectively, " $\mathrm{m}$ " is the mass $(\mathrm{g})$ of the solid in the solution, and $\mathrm{V}$ is the solution volume $(\mathrm{L})$. The kinetic parameters and the rate constants for adsorption were estimated using pseudo-first order and pseudo-second order kinetic equations of linear form and the Ho equation [32]. For the adsorption isotherm studies, reactors containing $\mathrm{Cd}(\mathrm{II})$ solutions of different concentrations in the $0-1200 \mathrm{mg} / \mathrm{L}$ range were shaken at $\mathrm{pH} 5$ condition, $2 \mathrm{~g} / \mathrm{L}$ sorbent dose and optimized contact time of $3 \mathrm{~h}$. Langmuir and Freundlich models were considered in order to fit the experimental isotherms of cadmium uptake by the wBDS-HAp surface.

\section{Results and Discussion}

\subsection{Thermal and structural characterization of the powders}

Figure 1 shows the thermal gravimetry (TG) curves of grafted apatites wBDS-HAp with different BDS content. All thermogravimetric curves have exactly the same paces, they differ only in the mass loss value. TG analysis shows two major mass losses depending on the chemical composition of the hybrid apatite wBDS-HAp (Fig.1). First, the evaporation of 
water $(3-6 \%)$ at $120^{\circ} \mathrm{C}$, then the combustion of BDS organic fractions (5-10\%) between 120 and $800^{\circ} \mathrm{C}$ and finally a slight loss beyond $800^{\circ} \mathrm{C}$ attributed to the water removal during the crystallization step. Note that the weight loss increases with the grafted BDS content in the apatite matrix, demonstrating the reactivity of this BDS with the $\mathrm{Ca}^{2+}$ ions.

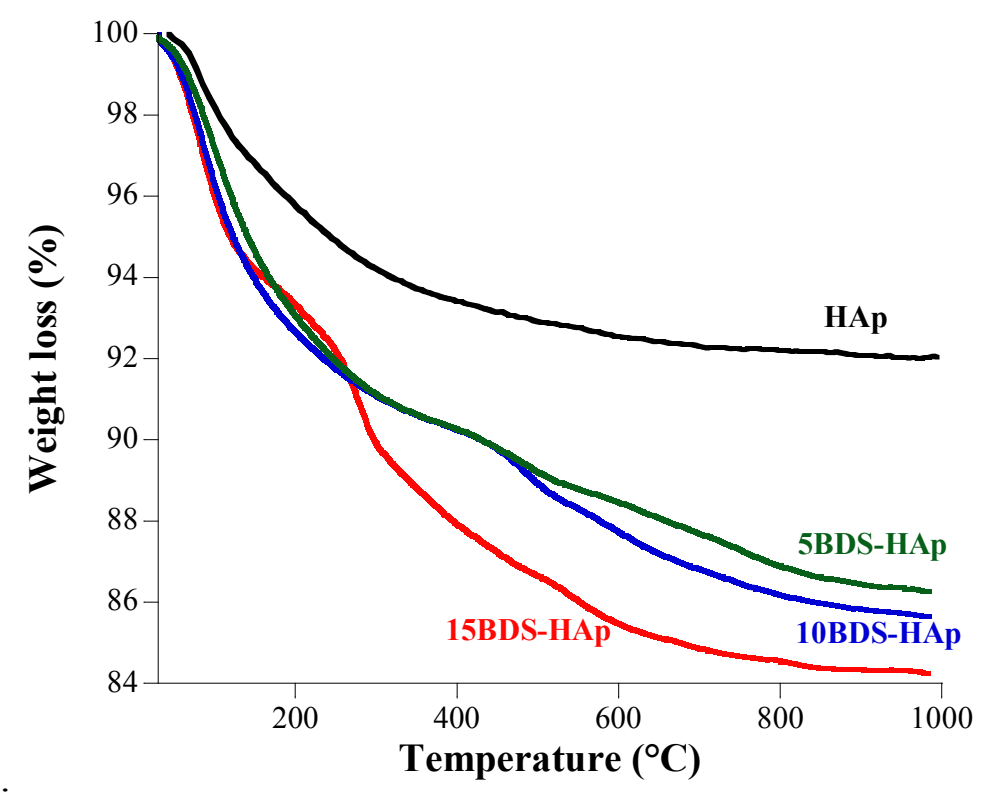

Fig. 1

The x-ray diffraction patterns of the dried hybrid materials show a poorly crystalline apatite structure largely depending on the BDS content (Fig.2a). The main crystalline peaks at 2 theta $=26^{\circ}, 32^{\circ}, 40^{\circ}, 47^{\circ}$ and $50^{\circ}$, confirm formation of the apatite structure with no secondary phosphate phase. Indeed, the presence of organic moieties inhibits the apatite crystallization by the creation of an important disorder in the apatite network, which thus reveals the presence of very small crystallites. This inhibition is due to the complexation of $\mathrm{Ca}^{2+}$ ions by the sulfonate functions attached to the organic chains of the sulfonated BDS graft. In consequence, $\mathrm{Ca}^{2+}$ ions react simultaneously with phosphate and sulfonate groups. The BDS graft in the HAp structure induces a structural disorder and allows a low thermal stability of the hybrid apatite (Fig.2b). Contrary to other BDS content, heat treatment of 15BDS-HAp at $800^{\circ} \mathrm{C}$ induces a partial conversion into $\beta-\mathrm{Ca}_{3}\left(\mathrm{PO}_{4}\right)_{2}$ and $\mathrm{CaSO}_{4}$. For low BDS content $(5 \%$ and $10 \%$ ), the apatite structure is preserved demonstrating that it is possible to substitute the 
$\mathrm{PO}_{4}$ groups by $\mathrm{SO}_{3}$ or $\mathrm{SO}_{4}$ groups. This substitution can be accompanied by the insertion of $\mathrm{Na}^{+}$ions in the apatite structure to get $\mathrm{Ca}_{10-\mathrm{x}} \mathrm{Na}_{\mathrm{x}}\left(\mathrm{PO}_{4}\right)_{6-\mathrm{x}}\left(\mathrm{SO}_{4}\right)_{\mathrm{x}}(\mathrm{OH})_{2}$ solid solution, which $\mathrm{Na}^{+}$ comes from either natural phosphate or sodium benzene-1,3-disulfonate precursor. This suggestion is in good agreement with the $\mathrm{Ca}_{10-\mathrm{x}} \mathrm{Na}_{\mathrm{x}}\left(\mathrm{PO}_{4}\right)\left(\mathrm{SO}_{4}\right)_{\mathrm{x}} \mathrm{F}_{2}(0 \leq \mathrm{x} \leq 6)$ solid solutions described elsewhere [33]. For environmental applications, no heat treatment is recommended for sulfonated organoapatites to maintain the surface properties and chemical composition of the adsorbents.
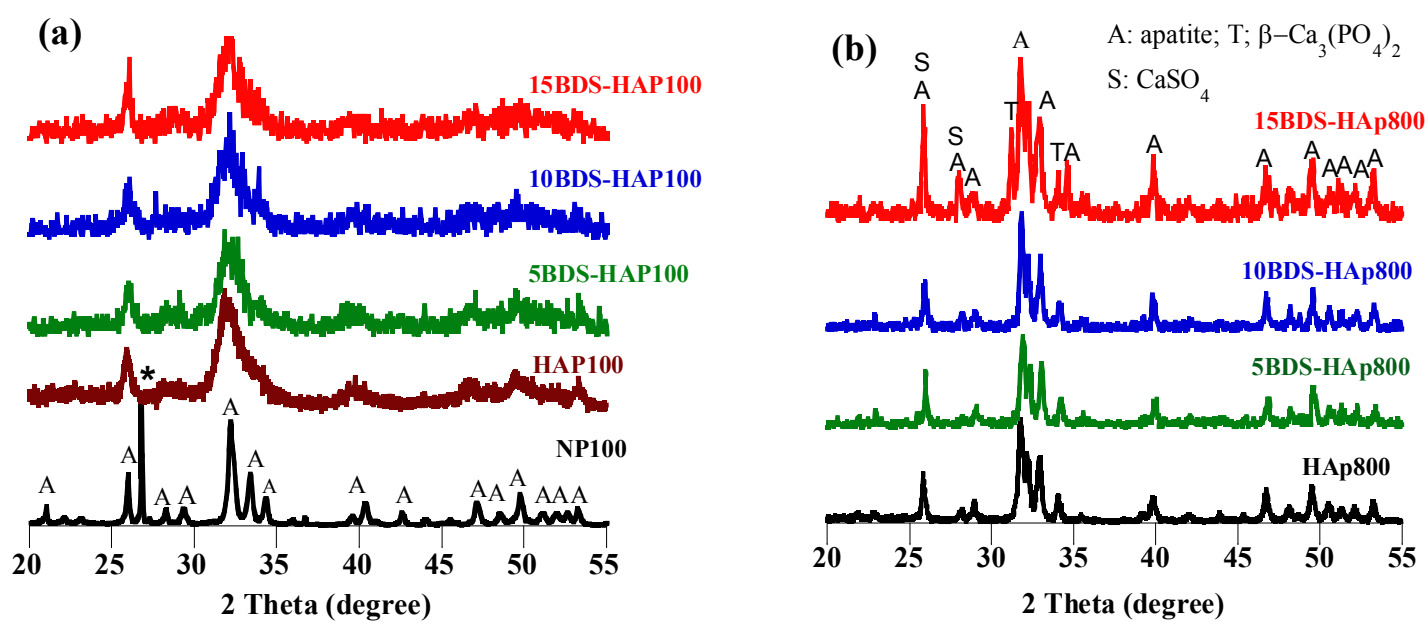

Fig. 2

Infrared spectra of the sulfonated HAps show the vibration bands of $\mathrm{PO}_{4}$ at $1090 \mathrm{~cm}^{-1}, 1030$ $\mathrm{cm}^{-1}, 962 \mathrm{~cm}^{-1}, 603 \mathrm{~cm}^{-1}$ and $565 \mathrm{~cm}^{-1}$ and those of $\mathrm{CO}_{3}{ }^{2-}$ especially for the starting NP raw material (Fig. 3). The band in the $3600-3700 \mathrm{~cm}^{-1}$ range corresponds to $\mathrm{OH}$ groups of the apatite. Besides these IR bands, the grafted BDS-HAp samples display organic $\mathrm{C}=\mathrm{C}$ bands around $1420-1450 \mathrm{~cm}^{-1}$, contrary to the pure HAp. This explains the exchange of $\mathrm{CO}_{3}^{2-}$ ions by sulfonate groups in the grafted materials. After grafting, new low intensity bands appear at 2000, 2300 and $2900 \mathrm{~cm}^{-1}$ (not visible at the scale of figure 3) attributed to C-H, S-C containing in BDS molecules. Heat treatment of the wBDS-HAp powders at $800^{\circ} \mathrm{C}$ degrades the organic matter to yield a pure HAp spectrum. However, it is very difficult to identify the $\mathrm{SO}_{4}$ bands since they overlap with $\mathrm{PO}_{4}$. 

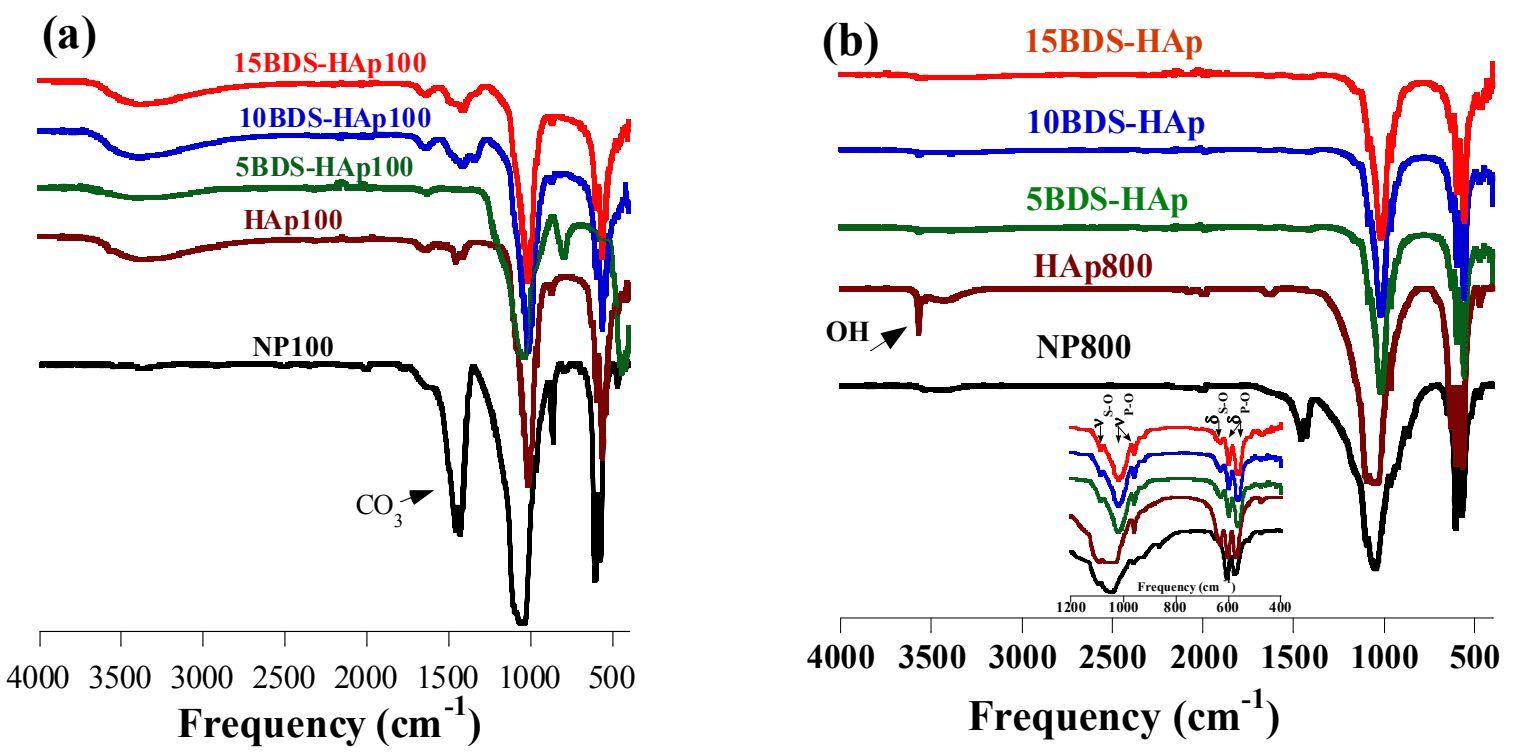

Fig. 3

The diffuse reflection spectra of wBDS-HAp nanopowders were recorded with a VARIAN CARY 50 spectrophotometer equipped with a DRA-CA-50 integration sphere (Fig. 4). wBDS-HAp nanocomposites exhibit an absorption band around $270 \mathrm{~nm}$, related to the $\pi-\pi^{*}$ transition centered on the benzenoid rings conjugated with the $\mathrm{S}=\mathrm{O}$ bond. The band is not visible in the pristine HAp. The grafting effect is illustrated by the intensity increase of the $270 \mathrm{~nm}$-band, together with $\Delta \lambda_{\max }=3 \mathrm{~nm}$-shift in the maximum with BDS loading. The shift is attributed to the chemical bonds established between the BDS groups and $\mathrm{Ca}^{2+}$ from apatite. This further confirms the grafting process of the BDS molecules on the apatite matrix. 


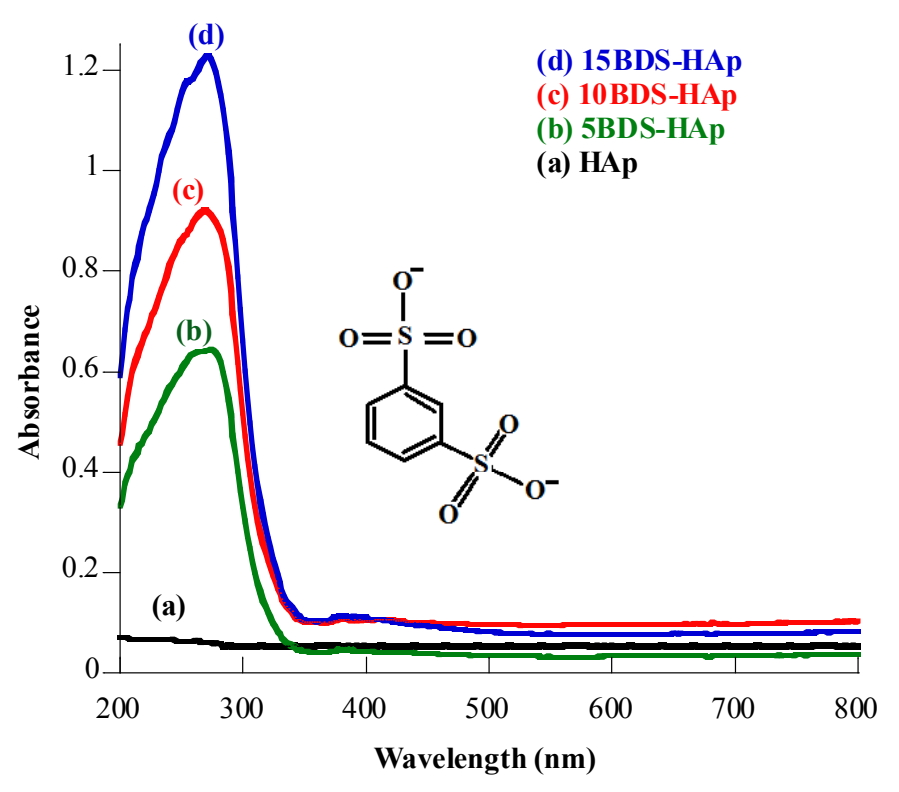

Fig. 4

The specific surface areas of the grafted materials were determined according to the BET method using nitrogen adsorption-desorption at $77 \mathrm{~K}$ (Fig. 5). Thus, the obtained isotherms are type IV according to the IUPAC classification, characteristic of adsorption in mesopores. In the case of 5BDS-HAp and HAp, the hysteresis is sharper, reflecting porosity different from those of 10BDS-HAp and 15BDS-HAp. Modification by BDS molecules improved the surface area of apatite especially with low BDS amount; and its increase has led to a progressive reduction of specific surface area. The specific surface areas, mesopore volumes and pore diameter for grafted samples are summarized in Table 1. An increase of surface area is observed in the sulfonated HAp as compared to the non-sulfated HAp. To explain this, the introduction of organosulfonates inhibits the crystal growth of wBDS-HAp particles, therefore promoting the pore creation at the sulfonated HAp surface. It is therefore possible that the BDS molecules were located inside pores. Using BJH calculation, the diameter of pores in the grafted apatite was between 9 and $12 \mathrm{~nm}$. 


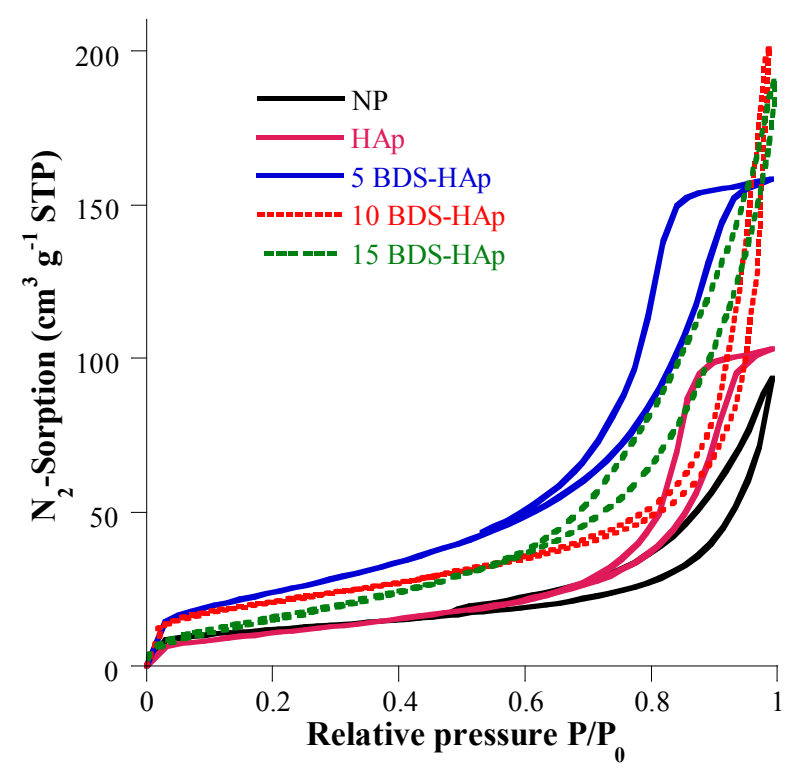

Fig. 5

Table 1.

\begin{tabular}{lccccccccc}
\hline & $\% \mathrm{Ca}$ & $\% \mathrm{P}$ & $\% \mathrm{~S}$ & $\mathrm{Ca} / \mathrm{P}$ & $\mathrm{Ca} /(\mathrm{P}+\mathrm{S})$ & Loss $(\%)$ & $\mathrm{S}_{\mathrm{BET}}\left(\mathrm{m}^{2} \mathrm{~g}^{-1}\right)$ & $\mathrm{V}_{\mathrm{p}}\left(\mathrm{cm}^{3} \mathrm{~g}^{-1}\right)$ & $\mathrm{D}_{\mathrm{p}}(\mathrm{nm})$ \\
\hline HAp & 38.62 & 16.36 & 0.07 & 1.82 & 1.81 & 4.0 & 100.0 & 35.3 & 12.0 \\
5BDS-HAp & 36.01 & 15.65 & 0.8 & 1.78 & 1.69 & 6.9 & 166.4 & 38.5 & 9.5 \\
10BDS-HAp & 35.04 & 15.08 & 1.50 & 1.79 & 1.63 & 7.8 & 193.3 & 44.2 & 9.0 \\
15BDS-HAp & 33.08 & 14.53 & 2.17 & 1.76 & 1.54 & 9.0 & 196.5 & 46.8 & 9.0 \\
\hline
\end{tabular}

The incorporation of BDS species in apatite matrix is proved by the sulfur analysis, showing its increasing amount in the solid when the introduced BDS content increases (Table 1). The decrease of the $\mathrm{Ca} / \mathrm{P}$ ratio may be explained by the incorporation of sulfonate groups. Therefore, chemical analyzis further confirms the incorporation of the sulfonated molecules in the apatite matrix and it is in good agreement with XRD results, thus making it is possible to obtain new materials with interesting adsorption properties. SEM in Fig. 6 shows the material structure, which consist in particle aggregates in $0.1 \mu \mathrm{m}-1 \mu \mathrm{m}$ range. The sulfur peak is clearly visible from the EDX analysis. TEM in Fig. 7 clearly reveals nanocomposite structure and the structure of HAp is clearly distinct from the 10BDS-HAp nanocomposite $(100 \mathrm{~nm}$ 
scale bar). HAp consists in bulk aggregates of ca. $50 \mathrm{~nm}$-long nano-plaques, meanwhile 10BDS-HAp consists in large aggregates of ca. 20-30 nm particles, whereas the apatite phase consists in ca. $50 \mathrm{~nm}$-long rod-like particles (Fig. 7). The two morphologies disappear upon heat treatment at $800^{\circ} \mathrm{C}$, resulting in a single morphology for both HAp and 10BDS-HAp structures, as higher magnification shows. This indicates the incorporation of sulfate groups in the hydroxyapatite structure.
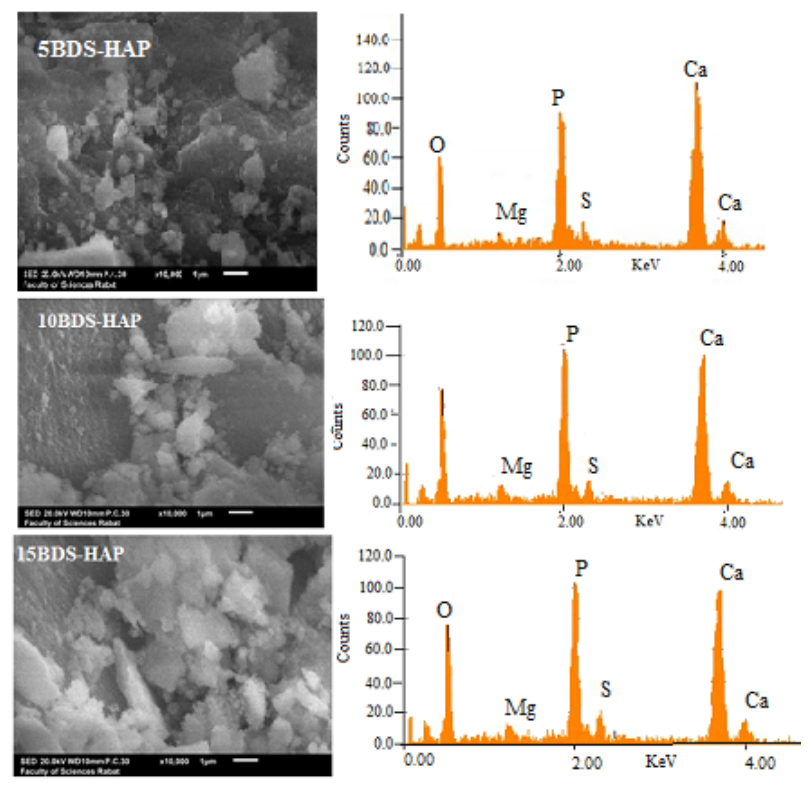

Fig. 6.

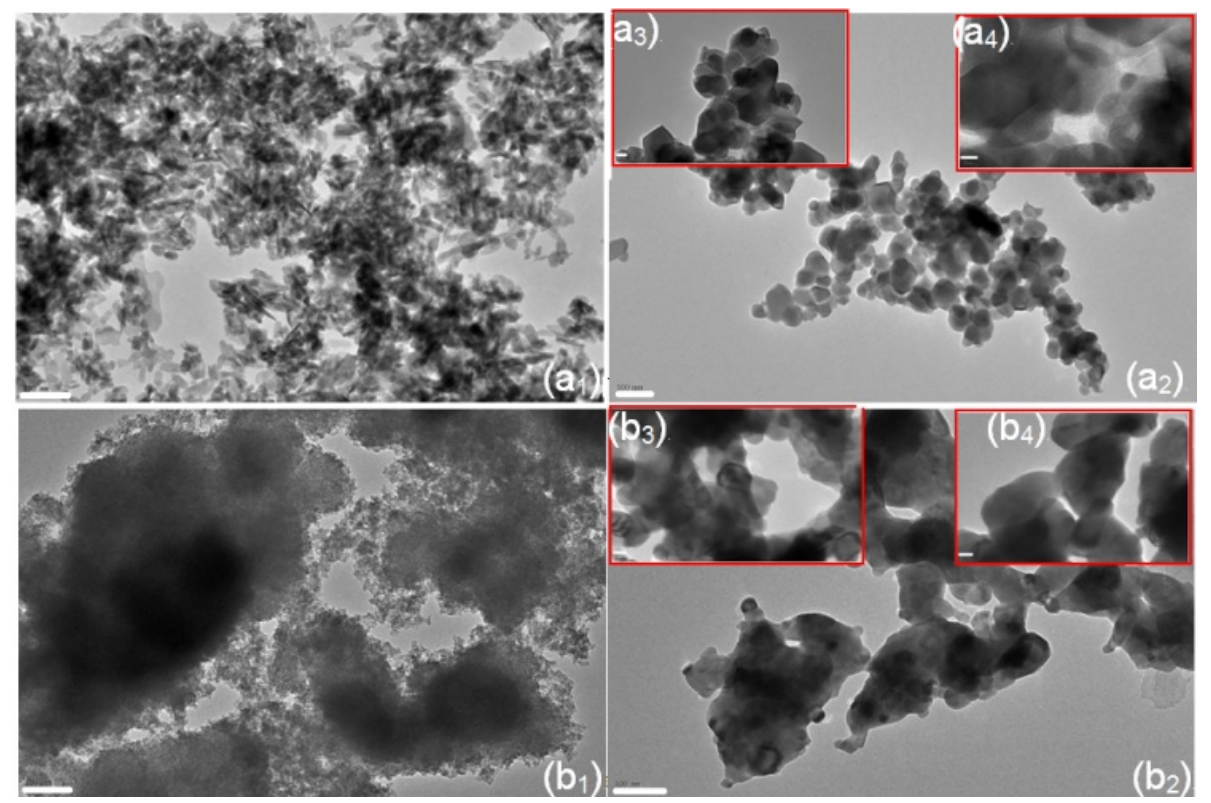

Fig. 7. 


\subsection{Surface properties}

To evaluate the sorption efficiency of novel wBDS-HAp sorbents and subsequently their surface properties in relation to the grafting rate and the affinity of $\mathrm{Cd}(\mathrm{II})$ ions toward the incorporated sulfonated functions, kinetics and adsorption isotherms of $\mathrm{Cd}(\mathrm{II})$ are studied. As illustrated by Fig. 8, we note that the time required to reach the surface saturation of the nanopowders slightly depends on BDS content in the hybrid apatite. With $100 \mathrm{mg} \mathrm{L}^{-1}$ as initial concentration of $\mathrm{Cd}(\mathrm{II})$, the equilibrium is reached within the first minutes, which is a fast time compared to that for HAp. We notice that the maximum sorption capacity of HAp is greater than that of NP but lower than that of BDS-HAp powders. This may be attributed to the greater specific surface area of HAp $\left(\mathrm{S}_{\mathrm{BET}}=100 \mathrm{~m}^{2} \mathrm{~g}^{-1}\right)$ compared to $20 \mathrm{~m}^{2} \mathrm{~g}^{-1}$ of NP [31]. A comparison of the relative adsorption values reveals that the sorption kinetics of $\mathrm{Cd}$ is more favored upon increasing the BDS content. This suggests that the BDS-grafted functions on the HAp surface provide more adsorptive sites for the removal of cadmium in water. Using the pseudo-first and pseudo-second order equations [32], the calculated values of $\mathrm{k}_{\mathrm{i}}$ and $\mathrm{q}_{\mathrm{e}, \mathrm{i}}$ as well as the regression coefficients $\left(R^{2}\right)$ are summarized in Table 2. First, we note that the values of $\mathrm{R}^{2}$ are closer to 1 for pseudo-second order kinetics than for pseudo-first order kinetics. This suggests that the sorption process is better modeled by the pseudo-second order equation. In fact, the best adsorption can be related to the high BDS content containing $-\mathrm{SO}_{3}$ groups to form $\mathrm{Cd}$....BDS-HAp complexes which sulfonates have more affinity versus $\mathrm{Cd}^{2+}$ ions. Few minutes were sufficient to remove the full $\mathrm{Cd}^{2+}$ ions contained in $100 \mathrm{mg} \mathrm{L}^{-1}$ aqueous solutions. The appearance of new active sites at sulfonated HAp surfaces could be responsible for the increase in Cd (II) removal. Hence, novel wBDS-HAp sorbents may possibly be agents for the decontaminated of water with heavy metals. 


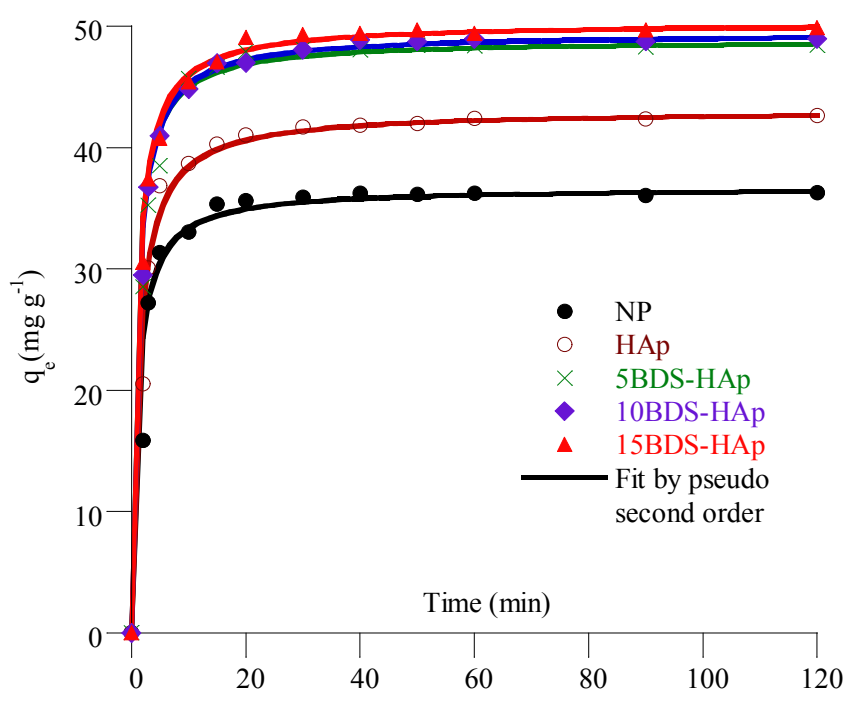

Fig. 8

\section{Table 2.}

\begin{tabular}{|c|c|c|c|c|c|c|}
\hline & & NP & HAp & 5BDS-HAp & 10BDS-HAp & 15BDS-HAp \\
\hline \multicolumn{2}{|c|}{ Experimental $\mathrm{q}_{\mathrm{e}, \max }(\mathrm{mg} / \mathrm{g})$} & 36.0 & 42.5 & 48.3 & 48.7 & 49.8 \\
\hline Pseudo first & $\mathrm{k}_{1}\left(\min ^{-1}\right)$ & 0.027 & 0.040 & 0.099 & 0.019 & 0.026 \\
\hline \multirow[t]{2}{*}{ order } & $\mathrm{q}_{\mathrm{e}, 1}\left(\mathrm{mg} \mathrm{g}^{-1}\right)$ & 1.20 & 6.58 & 7.85 & 7.85 & 1.81 \\
\hline & $\mathrm{R}^{2}$ & 0.5502 & 0.8501 & 0.7913 & 0.3188 & 0.6177 \\
\hline Pseudo & $\mathrm{k}_{2}\left(\min ^{-1}\right)$ & 0.188 & 0.026 & 0.083 & 0.158 & 0.108 \\
\hline second & $\mathrm{q}_{\mathrm{e}, 2}\left(\mathrm{~g} \cdot \mathrm{mg}^{-1} \mathrm{~min}^{-1}\right)$ & 36.15 & 42.89 & 48.73 & 48.70 & 49.76 \\
\hline order & $\mathrm{R}^{2}$ & 0.9998 & 0.9999 & 0.9999 & 0.9999 & 0.9999 \\
\hline
\end{tabular}

In the same way, we studied the effect of the initial concentration of Cd (II) ions on the adsorptive efficiency of nanopowders under the optimized conditions (initial $\mathrm{pH} \mathrm{5,} \mathrm{contact}$ time of $3 \mathrm{~h}$, sorbent dose of $2 \mathrm{~g} \mathrm{~L}^{-1}$, and temperature of $25^{\circ} \mathrm{C}$ ) (Fig. 9). The in-situ grafting of BDS molecules on HAp structure largely improves the metal immobilization into aqueous solution (Table 2). As described elsewhere, this adsorption is strongly influenced by the BDS 
content introduced into the apatite and the surface properties (specific surface, porosity, pore diameter) as well as the particle size.

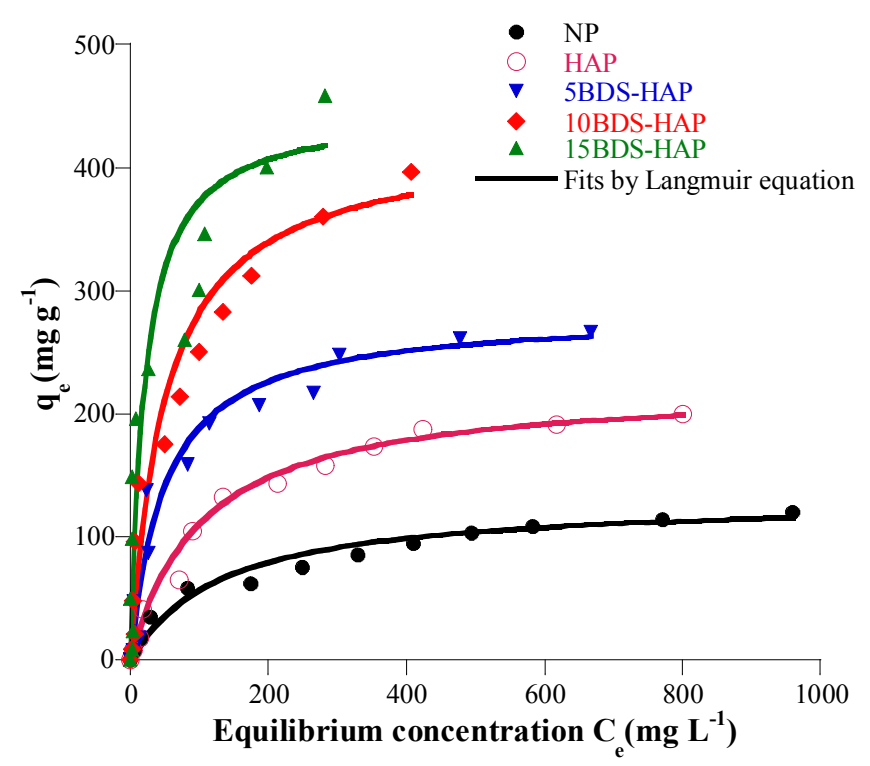

Fig. 9

In order to fit the experimental data, the Langmuir and Freundlich equations were used. Contrary to the Freundlich model, Langmuir equation was found appropriate to have a curve fitting of the experimental data $\left(\mathrm{R}^{2} \geq 0.99\right)$ (Fig.9) and the calculated $\mathrm{q}_{\mathrm{L}}$ values are closed to the experimental sorption capacity at equilibrium $\mathrm{q}_{\mathrm{e}, \max }$. As seen, the $q_{e, \max }$ value increases from $224 \mathrm{mg} / \mathrm{g}$ for HAp to $457 \mathrm{mg} / \mathrm{g}$ for 15BDS-HAp (Table 3), which was in good agreement with the increase of $\mathrm{S}_{\mathrm{BET}}$ and $\% \mathrm{~S}$. This situation confirms that the nature of cadmium adsorption on wBDS-HAp is chemical. Although the surface area of sulfonated hydroxyapatite increases with the BDS grafting content, their high adsorption capacity can be explained by two simultaneous processes: the first is the attachment of the metal by the surface of the grafted particles and the second is complexation $\mathrm{Cd} . . . \mathrm{SO}_{3}$. 


\section{Table 3.}

\begin{tabular}{lllllc}
\hline & NP & HAp & 5BDS-HAp & 10BDS-HAp & 15BDS-HAp \\
\hline Experimental q $\mathrm{q}_{\max }\left(\mathrm{mg} \cdot \mathrm{g}^{-1}\right)$ & 113 & 224 & 267 & 390 & 457 \\
$\mathrm{q}_{\mathrm{L}}$ from Langmuir modeling $\left(\mathrm{mg}^{\mathrm{g}} \mathrm{g}^{-1}\right)$ & 131.5 & 224.5 & 282.6 & 424.5 & 448.3 \\
\hline $\mathrm{S}_{\mathrm{BET}}\left(\mathrm{m}^{2} \mathrm{~g}^{-1}\right)$ & 20 & 100 & 166.4 & 193.3 & 196.5 \\
$\% \mathrm{~S}$ & 0.06 & 0.07 & 0.8 & 1.5 & 2.17 \\
\hline
\end{tabular}

These results highlight that cadmium removal is mainly controlled by the sorbent surface. However, these observations are compatible with three mechanisms: ionic exchange, dissolution/precipitation and complexation reaction. First, $\mathrm{Cd}(\mathrm{II})$ could be adsorbed at the powder surface on several sites. Then, the metal could diffuse into the structure, or complex at the hybrid apatite surface. After the fixation experiments, no argument allows to conclude that a solid solution $\mathrm{Ca}_{10-\mathrm{x}} \mathrm{Cd}_{\mathrm{x}} \mathrm{HAp}$ or Cd-hybrid HAp complexes forms because these hybrid sorbents exhibit poor crystallinity and their thermal treatment at high temperature reveals the degradation of BDS molecules, which are responsible for Cd adsorption.

For all sorption reactions, the control of $\mathrm{pH}$, calcium and phosphate in the solution was taken into account to clarify the sorption mechanism. If the $\mathrm{pH}$ of the mixture is acidic, the dissolution of the nanopowders is likely and may therefore be responsible for the release of calcium and phosphate. Small calcium concentration of $5 \mathrm{mg} / \mathrm{L}$ was obtained with no phosphate in solution since the equilibrium $\mathrm{pH}$ of the final solution is between 7 and 8 , which does not affect the HAp solubility under these conditions. This indicates little exchange between $\mathrm{Ca}^{2+}$ and $\mathrm{Cd}^{2+}$, but the reaction of $\mathrm{Cd}^{2+}$ with dissolved $\mathrm{PO}_{4}$ is rapid if it was to be a dissolution phenomenon. The effect of $\mathrm{pH}$ on adsorption capacity needs to be negligible under our conditions, especially the equilibrium $\mathrm{pH}$ values are between 7 and 8 . On the other hand and as described in the literature, the retention of metals in acidic $\mathrm{pH}$ favors the dissolution- 
precipitation mechanism. For HAp and NP adsorbents, $\mathrm{Cd}^{2+}$ is well known for its substitution of $\mathrm{Ca}^{2+}$ in the apatite structure, so that the ion-exchange mechanism should be more effective. However, it can react easily with the products of surface dissolution to form $\mathrm{Ca}_{10-}$ ${ }_{x} \mathrm{Cd}_{\mathrm{x}}\left(\mathrm{PO}_{4}\right)_{6}(\mathrm{OH})_{2}$. In this case, the $\mathrm{P}-\mathrm{OH}$ groups are responsible for the attachment of $\mathrm{Cd}^{2+}$ ions to the surface of HAp or NP samples. On the other hand, it should be noted that the best adsorption of wBDS-HAp versus $\mathrm{Cd}(\mathrm{II})$ is consistent with the complexation reactions. The possibility of $\mathrm{Cd}^{2+}$ ions entrapped in the pores also cannot be ruled out. From Fig. 10, the pH of the mixture gradually increases as a function of time until equilibrium and then remains stable, which depends on the chemical and surface characteristics of grafted sorbents in the presence of $\mathrm{Cd}(\mathrm{II})$ ions. Examination of the equilibrium $\mathrm{pH}$ of the powders in water shows that 10BDS-HAp induces an equilibrium $\mathrm{pH}$ of 7.8 , compared to 8.2 for HAp, which is more basic. In the presence of $\mathrm{Cd}$, the $\mathrm{pH}$ goes from an initial value of 7.8 to 7.1 ; significantly lower than $\mathrm{pH}=7.7$ for the $\mathrm{Cd} / \mathrm{HAp}$ reference system. We also note that the $\mathrm{pH}$ of the 10BDS-HAp suspensions in water (without $\mathrm{Cd}$ ) also increases with the percentage of BDS. This may be related to the phenomenon of wetting the surface of the nanocomposite that is able to fix the protons via a proton exchange mechanism.

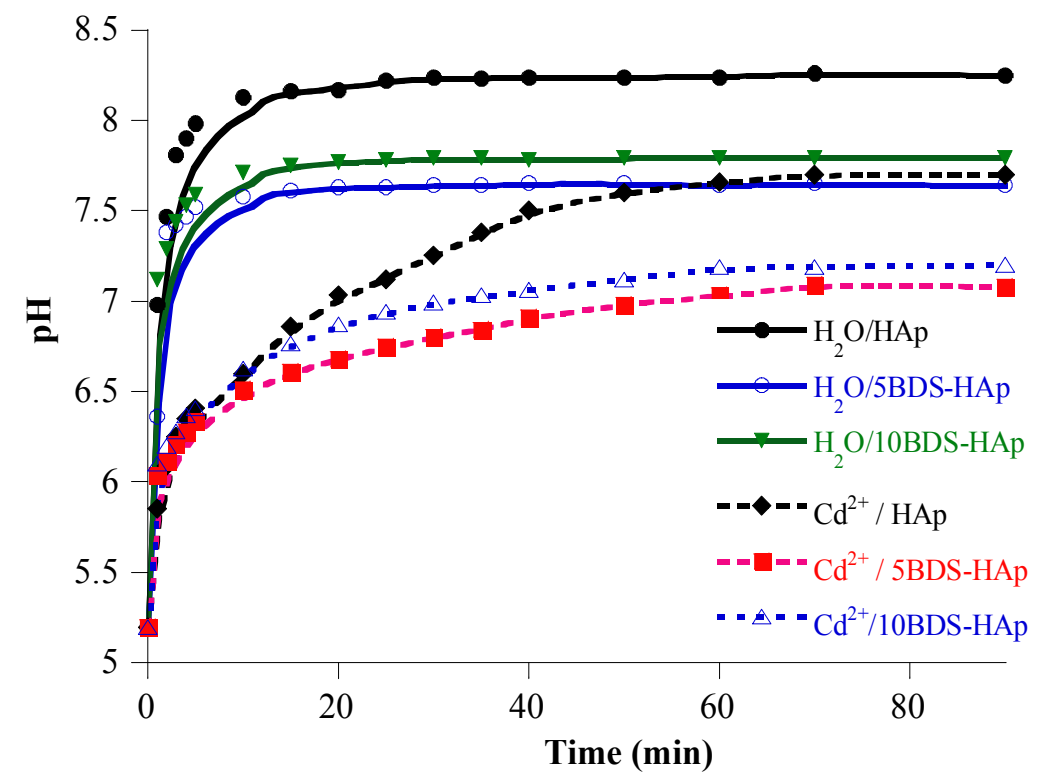

Fig. 10 
As previously described in various studies, particularly in the case of heavy metal adsorption $[15-16,22-24]$, the variation in $\mathrm{pH}$ is related to the protonic exchange between the solute and the adsorbent. These results relating to this variation in $\mathrm{pH}$ thus confirm that there is a change in the acid-base behavior during the $\mathrm{Cd}$ adsorption process on the wBDS-HAp nanocomposites and according to the BDS content therein.

A comparison between our results and those cited in the literature is shown in Table 4. The adsorption capacity of the grafted apatites wBDS-HAp is significantly higher than for minerals or composites [34-38], but sometimes lower than the performance of porous and grafted materials as reported elsewhere [39].

Table 4.

\begin{tabular}{lll}
\hline Adsorbents & $\mathrm{q}_{\max }\left(\mathrm{mg} \mathrm{g}^{-1}\right)$ & Reference \\
\hline Apple snail shell-aragonite & 81.3 & {$[34]$} \\
Melamine-based $\mathrm{NH}_{2}-\mathrm{SBA}-15$ & 71 & {$[35]$} \\
$\mathrm{Fe}_{3} \mathrm{O}_{4} / \mathrm{GO}$ & 91.29 & {$[36]$} \\
Fuctinalized graphene & 73.42 & {$[37]$} \\
Amino-functionalized $\mathrm{Fe}_{3} \mathrm{O}_{4} / \mathrm{SiO}_{2} \mathrm{MNPs}$ & 76.6 & {$[38]$} \\
PANI/PPy/HMS & 384.61 & {$[39]$} \\
3-(trimethoxysilyl)-1-propanethiol- & & \\
functionalized mesoporous silica & 85 & {$[40]$} \\
Natural carbonate fluorapatite (FAP) & 26.00 & {$[41]$} \\
Synthesized nano- hydroxyapatite & 88.50 & {$[42]$} \\
Commercial nano- hydroxyapatite & 64.07 & {$[43]$} \\
Carbonated hydroxyapatite modified & & \\
microfibrillated cellulose & 137.59 & {$[44]$} \\
Natural phosphate (Morocco) & 113 & This study \\
Converted hydroxyapatite HAp & 224 & This study \\
5BDS-HAp & 264 & This study \\
10BDS-HAp & 390 & This study \\
15BDS-HAp & 457 & This study \\
\hline
\end{tabular}




\section{Conclusions}

Sulfonated hydroxyapatite nanopowders were prepared by a modified and low-cost method is effective clearing agents for the Cd (II) removal in aqueous solutions. High BDS levels in the apatite matrix significantly improve the sorption capacity compared to the individual apatite and NP phase, related the affinity between $\mathrm{Cd}(\mathrm{II})$ and sulfur, and thanks to the more specific surface area and smaller size of the nanocrystals. Extension to other heavy metals should allow clarifying this affinity. The studied HAp nanocomposites show notable advantages, such as excellent adsorption capacity, shorter sorption reaction time and environment friendly sorbent with easy preparation procedure. This demonstrates the interest of HAp nanocomposites as potential soil and water remediation materials.

\section{References}

[1] C.N. Mulligan, R.N. Yong, B.F., Remediation Technologies for Metal-Contaminated Soils and Groundwater: An Evaluation, Eng. Geology, 60 (2001) 193-207. doi: 10.1016/S00137952(00)00101-0

[2] E. Silva, M.J. Lopez-Espinosa, J.M. Molina-Molina, M. Fernández, N. Olea, A. Kortenkamp, Lack of activity of cadmium in in vitro estrogenicity assays, Toxicol. Appl .Pharmacol. 216 (2006) 20-28. doi: 10.1016/j.taap.2006.04.002

[3] K. Tsuzuki, M. Sugiyama, N. Haramaki, DNA single-strand breaks and cytotoxicity induced by chromate(VI), cadmium(II), and mercury(II) in hydrogen peroxide-resistant cell lines, Environ. Health Perspect. 102 (1994) 341-342. doi: 10.1289/ehp.94102s3341

[4] R. Nazar, N. Iqbal, A. Masood, M.I.R. Khan, S. Syeed, N.A.Khan, Cadmium Toxicity in Plants and Role of Mineral Nutrients in Its Alleviation, Am. J.Plant Sciences 3 (2012) 14761489. doi: $10.4236 /$ ajps.2012.310178 
[5] E.N. Zare; M. M. Lakouraj, A. Ramezani, Efficient sorption of Pb(II) from an aqueous solution using a poly(aniline-co-3-aminobenzoic acid)-based magnetic core-shell nanocomposite, New J. Chem. 40 (2016), 2521-2529. doi: 10.1039/C5NJ02880A

[6] E.N. Zare EN, A. Motahari, M.Sillanpaa, Nanoadsorbents based on conducting polymer nanocomposites with main focus on polyaniline and its derivatives for removal of heavy metal ions/dyes: a review, Environ. Res. 162 (2018) 173-195. doi: 10.1016/j.envres.2017.12.025

[7] Y. Huang, X. Zeng, Li. Guo, J. Lan, L. Zhang, D.Cao, Heavy metal ion removal of wastewater by zeolite-imidazolate frameworks, Separ. Purif. Technol. 194 (2018) 462-469. doi: 10.1016/j.seppur.2017.11.068

[8] Q. Li, X. Chen, X. Chen, Y. Jin, J. Zhuang, Cadmium removal from soil by fulvic acidaided hydroxyapatite nanofluid, Chemosphere 215 (2019) 227-233. doi: 10.1016/j.chemosphere.2018.10.031

[9] A. Maleki, E. Pajootan, B. Hayati, Ethyl acrylate grafted chitosan for heavy metal removal from wastewater: Equilibrium, kinetic and thermodynamic studies, J. Taiwan Inst. Chem. Eng. 51 (2015) 127-134. doi: 10.1016/j.jtice.2015.01.004

[10] M.A.A. Zaini, Y. Amano, M. Machida, Adsorption of heavy metals onto activated carbons derived from polyacrylonitrile fiber, J. Hazard. Mater. 180 (2010) 552-560. doi: 10.1016/j.jhazmat.2010.04.069

[11] E. Dana, Adsorption of heavy metals on functionalized-mesoporous silica: A review, Micropor. Mesopor. Mat. 247 (2017) 145-157. doi: 10.1016/j.micromeso.2017.03.050

[12] E.N. Zare, M.M. Lakouraj, A. Ramezani, Effective adsorption of heavy metal cations by super-paramagnetic poly(aniline-co-m-phenylenediamine)@ $\mathrm{Fe}_{3} \mathrm{O}_{4}$ nanocomposite, Adv. Polym. Technol. 34 (2015) 21501. doi: 10.1002/adv.21501

[13] R. Hasanzadeh, P.N. Moghadam, N. Bahri-Laleh, E.N. Zare, Sulfonated magnetic nanocomposite based on reactive PGMA-MAn copolymer@ $\mathrm{Fe}_{3} \mathrm{O}_{4}$ nanoparticles: Effective 
removal of $\mathrm{Cu}$ (II) ions from aqueous solutions, Int. J. Polym. Sci. (2016) 2610541. doi: $10.1155 / 2016 / 2610541$

[14] S. Saoiabi, A. Gouza, H. Bouyarmane, A. Laghzizil, A. Saoiabi, Organophosphonatemodified hydroxyapatites for $\mathrm{Zn}(\mathrm{II})$ and $\mathrm{Pb}(\mathrm{II})$ adsorption in relation of their structure and surface properties, J. Environ. Chem. Eng. 4 (2016) 428-433. doi: 10.1016/j.jece.2015.11.036 [15] Y. Xu, F.W.Schwartz, S.J. Traina, Sorption of $\mathrm{Zn}^{2+}$ and $\mathrm{Cd}^{2+}$ on Hydroxyapatite Surfaces, Environ. Sci. Technol. 28 (1994) 1472-1480. doi: 10.1021/es00057a015

[16] Y. Daniels, S.D. Alexandratos, Design and Synthesis of Hydroxyapatite with Organic Modifiers for Application to Environmental Remediation, Waste Biomass Valor. 1 (2010) 157-162. doi: 10.1007/s12649-010-9011-0

[17] M.Y. Gelfer, C. Burger, B.S. Hsiao, S.C. D’Andrea, A. Y. Fadeev, Highly-ordered layered organo-mineral materials prepared via reactions of $n$-alkylphosphonic acids with apatite, J. Colloid Interface Sci. 295 (2006) 388-392. doi: 10.1016/j.jcis.2005.09.004

[18] A. Aissa, M.Debbabi, M. Gruselle, R.Thouvenot, P.Gredin, R. Traksmaa, K. Tonsuaadu, Covalent modification of calcium hydroxyapatite surface by grafting phenyl phosphonate moieties, J. Solid State Chem. 180 (2007) 2273-2278. doi: 10.1016/j.jssc.2007.05.016

[19] S. Saoiabi, K. Achelhi, S. Masse, A. Saoiabi, A. Laghzizil, T. Coradin, Organo-apatites for lead removal from aqueous solutions: A comparison between carboxylic acid and aminophosphonate surface modification, Colloid Surface A 419 (2013) 180-185. doi: 10.1016/jcolsurfa.2012.12.005

[20] S. Saoiabi, S. El Asri, A. Laghzizil, S. Masse, J.L. Ackerman, Synthesis and Characterization of Nanoapatites Organofunctionalized with Aminotriphosphonate Agents, J. Solid State Chem. 185 (2012) 95-100. doi:10.1016/j.jssc.2011.10.031 
[21] Y. Choia,Y. K. Hae, K.K. Jae, S. Lee, Direct synthesis of sulfonated mesoporous silica as inorganic fillers of proton-conducting organic-inorganic composite membranes, J.Membrane Sci. 357 (2010) 199-205. doi: 10.1016/j.memsci.2010.04.024

[22] M.P. Wei, H. Chai, Y.L. Cao, D.Z. Jia, Sulfonated graphene oxide as an adsorbent for removal of $\mathrm{Pb}^{2+}$ and methylene blue, J. Colloid Interface Sci. 524 (2018) 297-305. doi: 10.1016/j.jcis.2018.03.094

[23] M. M. Lakouraj, F. Mojerlou, E.Nazarzadeh Zare, Nanocomposite based on sodium alginate for sorption of heavy metal ions, Carbohydrate Polymers 106 (214) 34-41. doi: 10.1016/j.carbpol.2014.01.092

[24] C. Dong, F. Zhang, Z. Pang, G. Yang, Efficient and selective adsorption of multi-metal ions using sulfonated cellulose as adsorbent, Carbohydrate Polymers 151 (2016) 230-236. doi: 10.1016/j.carbpol.2016.05.066

[25] T. Suopajärvi, H. Liimatainen, M. Karjalainen, H. Upola, J. Niinimäki, Lead adsorption with sulfonated wheat pulp nanocelluloses, J. Water Process Eng. 5 (2015) 136-142. doi: 10.1016/j.jwpe.2014.06.003

[26] Y. Shen, B.L. Chen, Sulfonated Graphene Nanosheets as a Superb Adsorbent for Various Environmental Pollutants in Water, Environ. Sci. Technol. 49 (2015) 7364-7372. doi: 10.1021/acs.est.5b01057

[27] H. Asiabi, Y. Yamini, M. Shamsayei, E. Tahmasebi, Highly selective and efficient removal and extraction of heavy metals by layered double hydroxides intercalated with the diphenylamine-4-sulfonate: A comparative study, Chem. Eng. J. 323 (2017) 212-223. doi: 10.1016/j.cej.2017.04.096

[28] M. M. Lakouraj, F.Hasanzadeh, E. Nazarzadeh Zare, Nanogel and super-paramagnetic nanocomposite of thiacalix[4]arene functionalized chitosan: Synthesis, characterization and heavy metal sorption, Iranian Polym. J. 23 (2014) 933-945. doi: 10.1007/s13726-014-0287-y 
[29] S. El Asri, A. Laghzizil, A. Saoiabi, A. Alaoui, K. El Abassi, R. M'hamdi, T. Coradin, A novel process for the fabrication of nanoporous apatites from Moroccan phosphate rock, Colloids Surf. A, 350 (2009) 73-78. doi: 10.1016/j.colsurfa.2009.09.006

[30] S. El Asri, A. Laghzizil, T. Coradin, A. Saoiabi, A. Alaoui, R. M'hamedi, Conversion of natural phosphate rock into mesoporous hydroxyapatite for heavy metals removal from aqueous solution, Coll. Surfaces A 362 (2010) 33-38. doi: 10.1016/j.colsurfa.2010.03.036

[31] S. El Asri, A. Laghzizil, A. Alaoui, A. Saoiabi, R. M'Hamdi, K. EL Abbassi, A. Hakam, Structure and thermal behaviors of Moroccan phosphate rock (Bengurir), J. Therm. Anal. Calorim. 95 (2009) 11-15. doi: 10.1007/s10973-008-9114-Z

[32] Y.S. Ho, Review of second-order models for adsorption systems, J. Hazard. Mater. 136 (2006) 681-689. doi: 10.1016/j.jhazmat.2005.12.043

[33] A. Laghzizil, A. Bouhaouss, P. Barboux, R. Morineau, J. Livage, Mixed ionic conductivities in sodium fluoroapatites, Solid State Ionics 67 (1993) 137. doi: 10.1016/01672738(93)90319-X.

[34] B. Zhao, J. Zhang, W. Yan, X. Kan, C. Cheng, Y. Ouyang, Removal of cadmium from aqueous solution using waste shells of golden apple snail, Desalination Water Treat. 57 (2016) 23987-24003. doi: 10.1080/19443994.2016.1140078

[35] A. Shahbazi, H. Younesi, A. Badiei, Functionalized SBA-15 mesoporous silica by melamine-based dendrimer amines for adsorptive characteristics of $\mathrm{Pb}$ (II), $\mathrm{Cu}$ (II) and $\mathrm{Cd}(\mathrm{II})$ heavy metal ions in batch and fixed bed column, Chem. Eng. J. 168 (2011) 505-518. doi: 10.1016/j.cej.2010.11.053

[36] .H. Deng, X.R. Zhang, G.M. Zeng, J.L. Gong, Q.Y. Niu, J. Liang, Simultaneous removal of $\mathrm{Cd}(\mathrm{II})$ and ionic dyes from aqueous solution using magnetic graphene oxide nanocomposite as an adsorbent, Chem. Eng. J., 226 (2013) 189-200. doi: 10.1016/j.cej.2013.04.045 
[37] M. Yusuf, F.M. Elfghi, S.A. Zaidi, E.C. Abdullah, M.A. Khan, Applications of graphene and its derivatives as an adsorbent for heavy metal and dye removal: a systematic and comprehensive overview, RSC Adv. (2015) 50392-50420. doi: 10.1039/C5RA07223A [38] J.H. Wang, S.R. Zheng, Y. Shao, J.L. Liu, Z.Y. Xu, D.Q. Zhu, Amino-functionalized $\mathrm{Fe}_{3} \mathrm{O}_{4} / \mathrm{SiO}_{2}$ core-shell magnetic nanomaterial as a novel adsorbent for aqueous heavy metals removal, J. Colloid Interface Sci. 349 (2010) 293-299. doi: 10.1016/j.jcis.2010.05.010 [39] H. Javadian, F.Z. Sorkhrodi, BB.Koutenaei, Experimental investigation on enhancing aqueous cadmium removal via nanostructure composite of modified hexagonal type mesoporous silica with polyaniline/polypyrrole nanoparticles, J. Ind. Eng. Chem. 20 (2014) 3678-88. doi: 10.1016/j.jiec.2013.12.066

[40] S. Bagheri, M. M.Amini, M.Behbahani, G.Rabiee, Low cost thiol-functionalized mesoporous silica, KIT-6-SH, as a useful adsorbent for cadmium ions removal: A study on the adsorption isotherms and kinetics of KIT-6-SH, Microchemical Journal 145 (2019) 46046, doi: 10.1016/j.microc.2018.11.006

[41] H. Yaacoubi, O. Zidani, M. Mouflih, M. Gourai, S. Sebti, Removal of Cadmium from water using natural phosphate as adsorbent, Procedia Eng. 83 (2014) 386-393, doi: 10.1016/j.proeng.2014.09.039

[42] M.F. Elkady, M.M. Mahmoud, H.M. Abd-El-Rahman, Kinetic approach for cadmium sorption using microwave synthesized nano-hydroxyapatite, J. Non Cryst. Solids 357 (2011) 1118-1129, doi: 10.1016/j.jnoncrysol.2010.10.021

[43] Z. Zhang, M. Li, W. Chen, S. Zhu, N. Liu, L. Zhu, Immobilization of lead and cadmium from aqueous solution and contaminated sediment using nano-hydroxyapatite, Environ. Pollut. 158 (2010) 514-519, doi: 10.1016/j.envpol.2009.08.024

[44] S. Hokkanen, E. Repo, L.J. Westholm, S. Lou, T. Sainio, M. Sillanpaa, Adsorption of $\mathrm{Ni}^{2+}, \mathrm{Cd}^{2+}, \mathrm{PO}_{4}{ }^{3-}$ and $\mathrm{NO}_{3}^{-}$from aqueous solutions by nanostructured microfibrillated 
cellulose modified with carbonated hydroxyapatite, Chemical Engineering Journal 252 (2014) 64-74, doi: 10.1016/j.cej.2014.04.101 


\section{Table caption}

Table 1. Chemical analyses, specific surface area $\left(S_{B E T}\right)$, and average pore size $\left(D_{p}\right)$ from $N_{2}$ sorption for powders treated at $100^{\circ} \mathrm{C}$.

Table 2. Values of $\mathrm{k}_{\mathrm{i}}$ and $\mathrm{q}_{\mathrm{e}, \mathrm{i}}$ as obtained by using the both kinetic models for $\mathrm{Cd}(\mathrm{II})$ sorption on wBDS-HAp powders and pure HAp and NP. $\mathrm{R}^{2}$ indicate the correlation coefficients for the linear fits.

Table 3. Cadmium sorption capacities in relation with surface area and $\% \mathrm{~S}$ and the calculated $\mathrm{q}_{\mathrm{L}}$ values from Langmuir modeling of experimental sorption data.

Table 4. Adsorption capacities of $\mathrm{Cd}^{2+}$ ions by various adsorbents.

\section{Caption of figures}

Fig. 1. Thermal gravimetric analyses of pure and wBDS-HAp powders

Fig. 2. X-ray diffractograms of the wBDS-HAp powders compared to pure HAp and NP (a) dried at $100^{\circ} \mathrm{C}$ and (b) calcined at $800^{\circ} \mathrm{C}$.

Fig. 3. FTIR spectra of wBDS-HAp with different BDS amounts (a) dried at $100^{\circ} \mathrm{C}$ and (b) calcined at $800^{\circ} \mathrm{C}$.

Fig. 4. UV-Vis spectra of HAp and wBDS-HAp nanopowders.

Fig. 5. $\mathrm{N}_{2}$ adsorption-desorption on wBDS-HAp, HAp and NP powders dried at $100^{\circ} \mathrm{C}$.

Fig. 6. SEM (Left) to prove the particle morphology and EDX (Right) to verify the sulfur content.

Fig. 7. Selected TEM images of dried $\left(a_{1}\right)$ HAp and $\left(b_{1}\right)$ 10BDS-HAp nanocomposite (scale bar is $100 \mathrm{~nm}$ ). Images $\left(\mathrm{a}_{2}\right), \mathrm{a}_{3},\left(\mathrm{a}_{4}\right)$ of calcined HAP powder at $800^{\circ} \mathrm{C}$ (scale bars are $100 \mathrm{~nm}$, $20 \mathrm{~nm}$ and $10 \mathrm{~nm}$, respectively). Images $\left(b_{2}\right),\left(b_{3}\right),\left(b_{4}\right)$ of calcined 10BDS-HAp nanocomposite at $800^{\circ} \mathrm{C}$ (scale bars are $100 \mathrm{~nm}, 20 \mathrm{~nm}$ and $10 \mathrm{~nm}$, respectively). 
Fig. 8. Kinetics of $\mathrm{Cd}(\mathrm{II})$ removal $\left(\mathrm{q}_{\mathrm{e}}\right)$ by the wBDS-HAp powders compared to pure HAp and NP. Plain lines show the results of data fitting using the pseudo-second order Lagergren model.

Fig. 9. Effect of the initial concentration on the Cd(II) sorption of wBDS-HAp.

Fig.10. $\mathrm{pH}$ monitoring at equilibrium in the presence of wBDS-HAp in aqueous solution wit and without $\mathrm{Cd}$ (II) ions. For the visualization of the figure, results of NP are not presented since they are similar to those of HAp. 


\section{Supplementary material}

Figure S1 shows the steps of the experimental protocol.

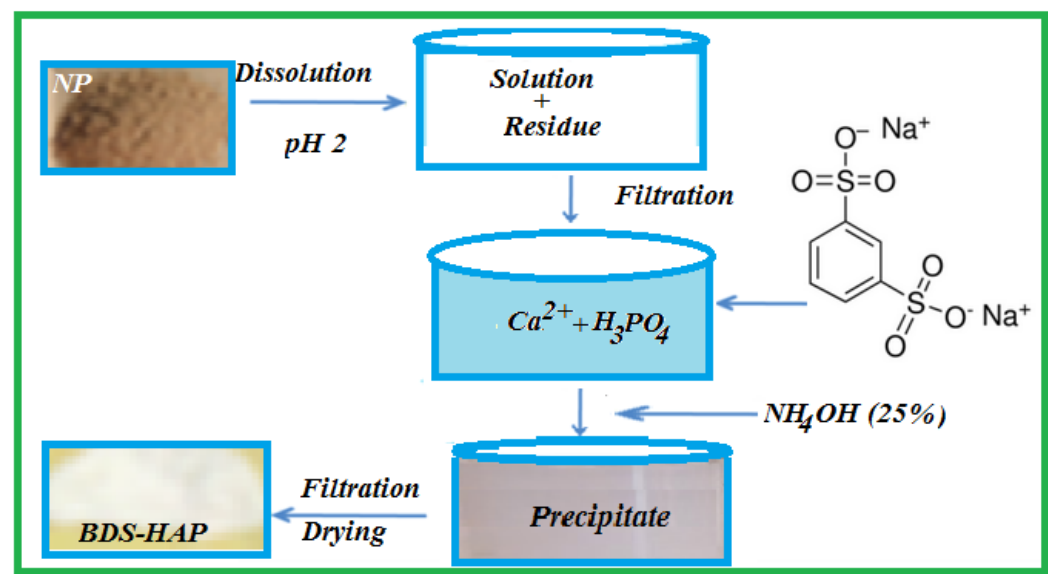

Figure S2. Effect of sorbent dose on the adsorption of Cd(II) ions of the wBDS-HAp apatites. The effect of adsorbent dose was also investigated, showing that the percent removal of $\mathrm{Cd}^{2+}$ ions by hybrid sorbents gradually increases with the added quantity of adsorbent until 1.5-2 range. Above this, the removal percentage of $\mathrm{Cd}^{2+}$ depends on the chemical composition of hybrid materials and it is complete for 10BDSHAp and 15BDS-HAp, indicating an ample saturation of their surfaces. For this purpose, a dose of $2 \mathrm{~g} \mathrm{~L}^{-1}$ has been taken for all sorption experiments.

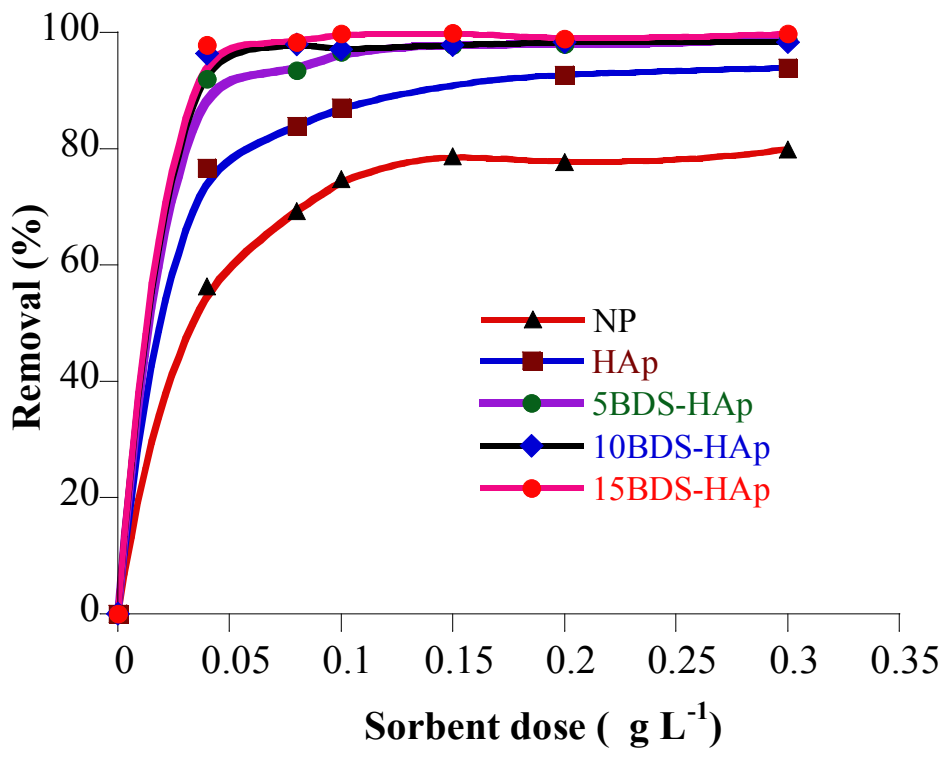

